\title{
THE EVALUATION OF EMPLOYEE SILENCE FROM THE PERSPECTIVE OF FOREIGN EMPLOYEES WORKING FOR INTERNATIONAL COMPANIES IN POLAND
}

\author{
Murat AYDINAYa
}

\begin{abstract}
The aim of this research is to evaluate organizational silence behavior from the perspective of foreign employees who work at the international companies in Poland. It is also aimed to find out "what issues employees remain silent about, the reasons for remaining silent, and how remaining silent affects employees" by considering the employee-manager relationships and to compare the findings based on the distinction between representations of eastern and western cultures. Ten foreign employees from ten different countries who work at international companies in Warsaw were selected based on maximum variation sampling. Depth interviews were conducted between November and December 2019 with these employees and content analysis method was used to analyze their responses. The themes that stand out from the participants' responses were summarized through tables and discussed in light of the relevant literature. The situations related to managers' attitudes, behaviors, perceptions, decisions, daily moods, and mentality are the most common issues for employees to remain silent about. While employees' culture and personality, and being afraid of managers' reactions are the main reasons for remaining silent, the silence causes some negative effects on employees' mood, efficiency, motivation, behaviors, and self-esteem. Organizational culture, managerial attitudes, employees' culture and personality have an effect on organizational silence. Hence, well-structured organizational structures and cultures will direct managers to develop positive behaviors, and eliminate the negative effects of managerial attitudes and behaviors on the employees. Additionally, managers working for international companies with employees from different countries should take into account the cultures, religions and personalities of the employees not to cause silence during organizational communication.
\end{abstract}

Keywords: Organizational silence, International company, Employee silence, Manager-employee communication

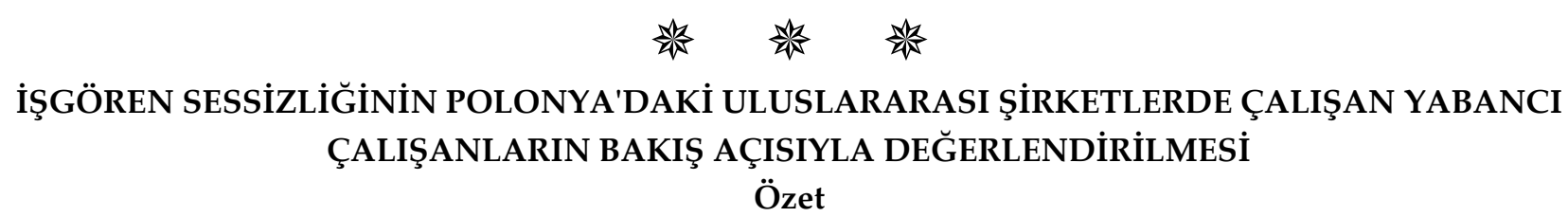

Mevcut araştırmanın amacı örgütsel sessizlik davranışını Polonya'daki uluslararası firmalarda çalışan yabancı çalışanların bakış açısıyla ele almaktır. Bu amaçla birlikte çalışanların sessiz kaldığı konular/durumlar, sessiz

a Dr. Conectys, murataydinay@gmail.com

Makale Geliş Tarihi: 11.05.2021, Makale Kabul Tarihi: 16.07.2021 
kalma nedenleri ve sessiz kalmanın çalışanlar üzerindeki etkilerini yönetici-çalışan iletişimi üzerinden değerlendirmek ve doğu ile batı kültürlerini temsil eden çalışanların yanıtları üzerinden karşılaştırmak da hedeflenmiştir. Maksimum varyasyon örneklemesiyle Varşova'daki uluslararası şirketlerde çalışan ve on farklı ülkeden olan on yabancı çalışan araştırmada yer almıştır. Bu çalışanlarla 2019 yılının Kasım ve Aralık aylarında derinlemesine görüşmeler yapılmış ve elde edilen cevaplar içerik analizine tabi tutulmuştur. Katılımcıların cevaplarında öne çıkan temalar tablolarla özetlenmiş ve ilgili literatür ışı̆̆ında tartışılmıştır. Yöneticilerin tutumları, davranışları, algıları, kararları, günlük ruh halleri ve bakış açıları gibi etkenler çalışanların en çok sessiz kaldığı durumlara karşılık gelmiştir. Çalışanların sahip olduğu kültür yapıları, kişilikleri ve yöneticilerin olası tepkilerinden korkmaları sessiz kalma davranışının asıl sebepleri arasında yer almışken; sessizlik davranışı çalışanların ruh hali, verimliliği, motivasyonu, davranışları ve benlik saygısı üzerinde bazı olumsuz etkilere neden olmuştur. Temel olarak örgütsel kültür, yönetsel tutumlar, çalışanların kültürü ve kişiliğinin örgütsel sessizlik davranışı için önemli değişkenler olduğu sonucuna varılmıştır. Bu sebeple iyi yapılandırılmış örgütsel yapı ve kültürlerin, yöneticileri olumlu tutum ve davranış geliştirmeye yönelteceği ve dolayısıyla çalışanlar üzerinde olumlu etkiler yaratacağı düşünülmüştür. Ayrıca örgütsel iletişim süreçlerinde yöneticilerin çalışanların kültürleri, dini inanışları, kişilikleri ve hassasiyetlerini göz önünde bulundurmasının, çalışanların örgütsel sessizlik davranışı geliştirmesinde azaltıcı etki göstereceği varsayılmıştır.

Anahtar Kelimeler: Örgütsel sessizlik, Uluslararası şirket, Çalışan sessizliği, Yönetici-çalışan iletişimi

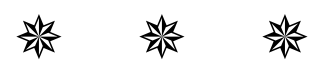

\section{Introduction}

Employee silence points to a critical issue that needs to be handled in the organizational life while employee voice has an effect on the group and organizational outcomes by leading to increased learning, decision making or improved organizational performance (Morrison \& Milliken, 2000). Accordingly, employee voice could be even more crucial for organizations with employees from different countries where race, ethnicity, national origin, and religion of employees are considered as a component of diversity in organizational life. Because diversity can contribute to achieving expected outcomes of organizations and contribute to their success (Cavise, 2019). Therefore, providing speaking comfort at the workplace to foreign employees or considering employee voice in organizations that have a multinational employee profile may help to achieve the expected effect from employees, hence organizational goals. Because employee voice positively affects employees and the organization itself, and facilitates organizational progress by supporting the integration of employees and organizations. Some of the positive effects of employee voice are as follows, organizational learning (Argyris \& Schon, 1978), organizational innovation (Nemeth, 1985), involvement in the decision-making (Timming, 2012), performance (Sherf et al., 2018), work engagement (Şimşek \& Gürler, 2019), motivation and increased productivity (Cavise, 2019), job satisfaction (Liang \& Yeh, 2020). Otherwise, the employees will be more likely to experience different organizational and personal problems as they are unable to speak up. In other words, when employee silence emerges in the organizations, it will negatively affect the development, success, and sustainability of the organizations (Dyne et al., 2003). In order to eliminate these negative effects, the employees should keep going to work effectively and even need to be more willing to take initiative roles and different responsibilities to achieve common goals or organizational 
success (Quinn \& Spreitzer, 1997). For this reason, the manager-employee communication process through the organizational life should be structured well. Because of understanding the effect of managers' role on organizational silence is getting more obvious, as it is stated that an effective organizational structure that gives comfort to employees for speaking up can be shaped by organizations/managers (Askari et al., 2015, as cited in Paksirat \& Taheri, 2018, p. 39). Where the managers are unable to lead all these processes and to provide speaking comfort for employees, the employee silence will spread to the whole organization, and the organizational silence that defined as a dangerous obstacle for organizational change and development will emerge as a collective phenomenon (Morrison \& Milliken, 2000).

The concept of organizational silence is seen as significant to be examined, and it is explained by different perspectives based on the reasons behind the silence. For example, Nielsen (2003) underlines some factors to explain the reasons for silence in organizations: (a) fear (b) shyness/embarrassment (c) looking at the understanding of responsibility from a narrow perspective (d) limited conditions for attempting to speak up (e) lack of organizational political skills.

However; it is thought that this classification based on 3 different reasons explains the silence better (Shojaie et al., 2011). Organizational reasons correspond to the components that define the organization itself (Milliken et al., 2003) such as decision-making policies, organizational procedures, the level of organizational effectiveness and performance, organizational structure and culture (Shojaie et al., 2011; Slade, 2008). Personal reasons are related to employees themselves depending on the idea that all employees are an individual. For example; general mindset of employees, employees' concern about losing their jobs or promotions and not being seen as a team player, the effect of personality traits on silence, lack of experience, the fear of damaging relations with peers or managers and being labeled as a troublemaker, embarrassing and harming someone in the organization or avoid to make feel them threatened, the idea that talking wouldn't make a difference (Milliken et al., 2003; Liu et al., 2009; Shojaie et al., 2011). Managerial reasons refer to the general attitudes of managers or the communication between managers and employees (Morrison \& Milliken, 2000). For example negative feedback, problem-solving approaches and toxic behaviors of managers, not feeling safe psychologically due to the behaviors of the managers, and managers' implicit beliefs that employees are lazy or unreliable (Botero \& Dyne, 2009; Brinsfield, 2013; Liu et al., 2009).

In the light of all these reasons, it is possible to assume that the managers have a significant effect on silence. Because the people who can carry out supportive activities in creating an organizational structure that gives employees speaking comfort are the managers. This assumption is supported by different findings where it is claimed that lack of communication and problems within the organization, official authority, subordinates' concern about receiving negative feedback, and top managers' and

| 958 | supervisors' attitudes are the main reasons for silence (Brinsfield, 2009). Additionally, it is also stated that silence basically/mostly occurs depending on the attitudes and beliefs of managers (Morrison \& Milliken, 2000; Nafei, 2016) such as; negative feedbacks and implicit beliefs of managers, managers' characteristics that affect organizational culture, financial background of managers, and policies of managers are some of these attitudes. 
Based on the critical effect of managers on organizational silence behavior, organizational silence is examined in this study through the perspective of foreign employees who work at the international companies in Warsaw/Poland considering their manager-employee relationships. As a result of this study, it is aimed to find out "what issues employees remain silent about, the reasons for remaining silent, and how remaining silent affects employees" by conducting depth interviews. Furthermore, it will be significant to consider silence behavior from the employees' perspective that represent different cultures and to evaluate the perceptions or reactions towards silence between eastern and western cultural representations. Therefore, this study will provide practical implications for organizational life while it will contribute to the literature on organizational silence in the context of cultural differences.

\section{A. LITERATURE REVIEW}

\section{Organizational Silence and Its Dimensions}

Organizational silence is generally defined as a phenomenon that underlies the preference of employees to remain silent on organizational problems (Morrison \& Milliken, 2000). In other words, organizational silence is a concept that emphasizes employees hide their suggestions/opinions and do not share their problems at the workplace with their superiors (Durak, 2014; Dyne et al., 2003; Lam \& Xu, 2019). While Premeaux \& Bedeian (2003) draw attention to silence regarding problems with managerial or functional tasks to define organizational silence, Liu et al. (2009) point to an inefficient organizational process involving low levels of participation to define organizational silence. Therefore, organizational silence can be defined as employees' preference or need to remain silent as they cannot express their problems or share their ideas that might affect organizational improvement.

Organizational silence is classified into three dimensions: acquiescent silence, defensive silence and prosocial silence.

a-) Acquiescent Silence: This dimension of organizational silence is the lack of reactions or responses given by employees about their problems and concern. In other words, acquiescent silence points to the unwillingness of employees for speaking up (Dyne et al., 2003) as they believe that their opinion will not be considered and the existing situation will not change when they express themselves (Çavuş et al., 2015; Pinder \& Harlos, 2001).

b-) Defensive Silence: This dimension implies that employees prefer to remain silent in order to avoid negative reactions (threats or other negativities) that may occur in case of speaking up (Dyne et al., 2003). Thus, employees keep going to remain silent strictly despite the fact that they know that they will contribute to the organizations in case of offering their ideas (Pinder \& Harlos, 2001; Karakas, 2019). Moreover, they hide their mistakes that are made at the workplace (Dyne et al., 2003) to avoid being subject to some changes in their working conditions (e.g. losing the job, damaging their relations in the organization, being strained on working more than usual hours, etc) (Deniz, 2019; Eroğlu et al., 2011; Miliken et al., 2003).

c-) Prosocial Silence: This dimension refers that the employees remain silent to protect other members in the organization and/or the organization itself (Acaray et al., 2015; Dyne et al., 2003). In this 
case, the employees concern that there will be a potential harm for others in the organization when they express themselves. Thus, this dimension corresponds to the proactive behaviors that aim to prevent other members from different kinds of threats (Podsakoff et al., 2000).

\section{B. METHODOLOGY}

\section{Research Aims and Questions}

This research's aim is to evaluate organizational silence through the perspective of foreign employees who work at the international companies in Warsaw/Poland based on their manageremployee relationships. The research questions of this study are as follows.

1. What issues, in general, do employees remain silent about?

2. What are the reasons for remaining silent for employees?

3. How does remaining silent affect employees?

4. Is there any difference between the opinions and reactions of employees who represent western and eastern cultures on organizational silence?

\section{Study Group}

Ten full-time foreign employees who work at international companies in Warsaw took part in this research as participants. The reason for choosing these employees is to describe the situations in which silence behavior occurs based on the current manager-employee communication process while working in a different country other than their own countries with a manager from a different culture. In other words, these employees were preferred in order to be able to make a cross-cultural comparison between employees' perception and reactions towards silence behavior, and the effects of silence on them. Maximum variation sampling was used in determining the participants. The main aim of this sampling type is to consider the highest level of variation observed in the characteristics of individuals who can represent the research problem (Yıldırım \& Şimşek, 2016). Accordingly, the criteria representing the research aims were taken into consideration (McNabb, 2015), and the variation criteria required for the research (Baltac1, 2018; Creswell \& Clark, 2016) were determined. The first selection criterion was the condition that the participants work in international companies. The reason for the preference of international companies was associated with the assumption of a higher possibility to reach out to foreign employees in these companies. Hence, it would be more possible to have interviews with participants from different cultures to make comparisons. Therefore, participants' countries were considered as another selection criterion to enrich the findings by making possible comparisons between groups. Additionally, it was also taken into consideration that the participants' current managers were not from their own cultures, and employees needed to work in the departments related to information technology (depending on the assumption of these departments have more foreign employees and these employees have similar/potential problems or manager-employee relationship). As a result, the sample of this study consisted of 10 participants who may represent the eastern (5 participants) and western cultures (5 participants) based on variation criteria and the opinions of two experts. 
Ten participants who took part in the study according to selection criteria were divided into two groups of five people based on the assumption that the participants in each group share similar cultural background or geography. Accordingly, two different groups were created that represent eastern and western cultures depending on cultural similarities, geographic locations and historical background and etc. (Wikipedia, 2003; Pew Research Center, 2018; Hofstede Insights, n.d.; Adl.org, n.d.). While the participants from Austria, Denmark, Spain, Germany, and Hungary represent the western culture; the participants from Turkey, India, Uzbekistan, Egypt, and China represent the eastern culture.

The demographic data shows that six of the participants are men while four of them are women. The age range of the participants differs from 23 to 35 years (the average is 28.9), and seven of them are single. As educational background, three of the participants hold bachelor's, six of them hold master's, and one of them holds a Ph.D. degree. Total working time in both Poland and their current organizations ranges from 1 to 8 years (the average working time in Poland: 5 years, the average working time at the current organization: 4.1 years).

The participants work in IT or similar departments with different professions such as software developer, data analyst, planning specialist, project specialist/manager, java developer, CRM developer, IT researcher, sourcing specialist etc. While four of the participants have never changed a workplace in Poland, three of them have changed two workplaces and three of them have changed one workplace. The reasons for choosing a new workplace for these employees are "salary, desire to work in an international and/or corporate company, unfriendly working environment, the first job's being not suitable for their career plan, a dispute with a manager, working hours and managers' attitudes".

\section{Data Collection and Analysis}

The depth interviews were conducted with ten foreign employees who work at international companies in Warsaw between November and December 2019, and interviews lasted 50 minutes on average. During these interviews, demographic questions (age, education, marital status, total working time in Poland, etc.) and open-ended questions that created based on the organizational silence scale developed by Çakıcı (2008) were addressed to the participants. These open-ended questions were determined based on participants' answers to the following question.

Can you share your problems, concerns, or suggestions related to your job or workplace with your managers in general?

\section{( ) Yes ( ) No ( ) I prefer to remain silent on certain issues}

Three open-ended questions were addressed to the participants who chose one of these answers: "No" or "I prefer to remain silent on certain issues". These questions were "What issues, in general, do you remain silent about?", "What are your reasons for remaining silent?" and "How does remaining silent affect you?" Through these questions, it is aimed to find out what issues employees remain silent about, the reasons for remaining silent and how remaining silent affects employees. Additionally, the question of "What are the situations/factors that facilitate expressing yourself to your managers?" was addressed to the participants who chose the answer of "yes". 
The content analysis method was used to analyze the data. This is an analysis type that aims to gather specific contents from the collected data and organize them in the form of codes and themes (Yıldırım \& Şimşek, 2016). The themes reached as a result of the analysis were evaluated by 3 different independent researchers. Thus, the themes that stand out from participants' responses to these questions are summarized and presented in three tables. Following each of these tables, the themes were evaluated and the original form of the responses given by the participants was taken part after the relevant evaluations to clarify the prominent issues, reasons, or effects.

\section{FINDINGS}

Table 1 and Table 2 include the responses for questions that aim to find out the issues that employees generally remain silent about, the reasons for remaining silent, and the effect of remaining silent on employees. Additionally, Table 3 includes the responses for the question of what are the situations/factors that facilitate expressing yourself to your managers. First of all, the responses of employees who remain silent will be evaluated.

\section{The Employees Who Remain Silent}

Table 1 shows the thematic summaries of employees' responses that remain silent based on three questions. The evaluations for these themes through three questions and the original form of the responses given by the participants are below.

Table 1. The Employees Who Remain Silent

\begin{tabular}{|c|c|c|}
\hline \multicolumn{3}{|l|}{$\begin{array}{l}\text { Number of Participants: } 2 \\
\text { Countries of Participants: Egypt and China }\end{array}$} \\
\hline $\begin{array}{l}\text { What issues, in general, do you remain silent } \\
\text { about? }\end{array}$ & $\begin{array}{l}\text { What are your reasons for remaining } \\
\text { silent? }\end{array}$ & $\begin{array}{l}\text { How does remaining silent affect } \\
\text { you? }\end{array}$ \\
\hline $\begin{array}{l}\text {-Manager's negative attitudes, } \\
\text {-Manager's discriminatory behavior, } \\
\text {-Insensitivity of manager, } \\
\text {-Some culture-specific reactions of managers, } \\
\text {-Situations where the content of the speech } \\
\text { might be perceived as a problem. }\end{array}$ & $\begin{array}{l}\text {-Being afraid of managers' negative } \\
\text { reaction, } \\
\text {-The effect of participants' culture, } \\
\text {-Refraining from being too aggressive in } \\
\text { response, } \\
\text {-Observing the negative experiences of } \\
\text { other members in the workplace. }\end{array}$ & $\begin{array}{l}\text {-Getting angry, } \\
\text {-Experiencing low motivation, } \\
\text {-Feeling of suppression, } \\
\text {-Working with low efficiency. }\end{array}$ \\
\hline
\end{tabular}

a-) The issues that employees remain silent about: Employees remain silent on many different issues throughout their organizational life. Some of the issues for the employees who do not speak up and remain completely silent about are related to the behaviors, attitudes, and perceptions of their managers. These issues can be reached out from the following statement:

"Of course, I cannot talk, when it is about my manager. I mean I do not want to talk about my manager's negative attitudes and discriminatory behaviors. Also, about some of his culture-specific reactions that Polish managers generally have. They do not show the same interest to foreign employees as they show to the locals. So, you can feel their insensitivity. This is the same in discrimination. They can give priority to local employees when making vacations and work plans. Or you can feel some negativity because of your nationality and religion, even it is implicit." (Participant from Egypt) 
These employees also remain silent to avoid any misunderstandings that may occur depending on the speech content. Accordingly, they can just speak up about ordinary issues when they believe that the speech content will not be perceived as a problem. These issues can be reached out from the following statement:

"I remain silent when the content of the speech will be perceived as a problem. So, I just talk about ordinary topics. Because even though I have never experienced it, I witnessed what kind of reactions that other employees exposed. They just wanted to talk about some situations that they perceived as problems. They were foreign employees too. That's why I think it's better to remain silent until I gain experience and find another job." (Participant from China)

b-) The reasons for remaining silent: The reasons for remaining silent for these employees are attributed to several reasons. Some of these reasons are based on employees' culture and personality, and fear of managers' negative attitudes. These reasons can be reached out from the following statement:

"I remain silent because I am afraid that my manager will show negative attitudes if I talk about his negative behaviors. Also, it will be perceived as if I am complaining about him. In fact, I am afraid that he will even fire me although it is not easy to fire someone according to the current laws and it takes a long time. Maybe we're having trouble partly because of my own culture. In general, we might conflict with my manager due to differences in doing business and solving problems. On the other hand, I remain silent because I avoid reacting very aggressively if I give a reaction to his behaviors during our conversation. So, remaining silent is the best option." (Participant from Egypt).

There are some other reasons for remaining silent such as; observing a negative experience of an employee who subjected to the destructive behaviors of the manager since that employee gave a reaction to the manager and refraining from the manager's reactions in general. These reasons can be reached out from the following statement:

"I remain silent since I saw what reactions those who objected. For example, the managers hinted at employees as "if you are not OK with your job, you can quit" and "if you quit, you have to find a job within 30 days otherwise your legal permits will be canceled". For these reasons, I remain silent and try to be more patient." (Participant from China)

c-) The effect of remaining silent on employees: Remaining silent causes some effects on employees' mood, productivity, and motivation. These effects can be reached out from the following statements:

"I get angry but I remain silent since I have experienced that silence works most of the time." (Participant from Egypt)

"My motivation decreases. I feel suppressed and start to work less efficiently than usual." (Participant from China) 


\section{The Employees Who Speak Up Occasionally}

Table 2 shows the thematic summaries of employees' responses who can speak up occasionally based on three questions. The evaluations for these themes through three questions and the original form of the responses given by the participants are below.

Table 2. The Employees Who Speak Up Occasionally

\begin{tabular}{|c|c|c|}
\hline $\begin{array}{l}\text { What issues, in general, do you remain silent } \\
\text { about? }\end{array}$ & $\begin{array}{l}\text { What are your reasons for remaining } \\
\text { silent? }\end{array}$ & $\begin{array}{l}\text { How does remaining silent affect } \\
\text { you? }\end{array}$ \\
\hline $\begin{array}{l}\text {-Working conditions, } \\
\text {-Scheduling overtime or vacation days } \\
\text {-Manager's way of doing business } \\
\text {-In situations that will be perceived as } \\
\text { complaining about the manager, } \\
\text {-Other members' problems, } \\
\text {-The unpredictable reactions depending on the } \\
\text { manager's mood, } \\
\text {-Manager's negative attitudes, } \\
\text {-The situations caused by manager's lack of } \\
\text { vision. }\end{array}$ & $\begin{array}{l}\text {-Managers' refusal to accept their own } \\
\text { discriminatory behavior, } \\
\text {-Not being perceived as a constant } \\
\text { complainer, } \\
\text {-Legal processes and permits in the } \\
\text { country, } \\
\text {-Economic satisfaction of the current } \\
\text { job, } \\
\text {-Worrying about being discriminated } \\
\text { against, } \\
\text {-The problem is others', } \\
\text {-Supervisor's unreasonable reactions, } \\
\text {-The potential of the manager to react } \\
\text { adversely, } \\
\text {-The feeling of despair about being } \\
\text { justified, } \\
\text {-Avoiding stress. }\end{array}$ & $\begin{array}{l}\text {-Getting angry, } \\
\text {-To question himself/herself, } \\
\text {-Worrying about being misunderstood, } \\
\text {-Worrying that all life will be } \\
\text { negatively affected, } \\
\text {-Not sharing useful information, } \\
\text {-Experiencing stress, } \\
\text {-Feeling no effect, } \\
\text {-Experiencing low motivation, } \\
\text {-Feeling obstacles for personal } \\
\text { developments, } \\
\text {-Working with low efficiency. }\end{array}$ \\
\hline
\end{tabular}

a-) The issues that employees remain silent about: Some issues for the employees who speak up occasionally to remain silent about are related to their working conditions and personal experiences at their workplaces. These issues can be reached out from the following statement:

"I would like to talk about working conditions but prefer to remain silent. Because there is discrimination between employees on scheduling overtime or vacation days. Depending on the requirements of our job, we may need to work on public holidays. But priority is given to Christian friends. For example, for the Christmas holiday. Yes, we are not Christian but this holiday is for everyone. Our manager can make a working schedule without favoring anyone. If he would ask and share his idea about giving priority to them since it is a special day, we could be OK with that idea. $B u t$ he does not. He makes the same plan every year. I tried to express it several times, but the reaction of my manager was a bit harsh and unacceptable, so I prefer to remain silent." (Participant from Turkey)

Some other issues for these employees to remain silent are about the situations that will be perceived as if the employees are complaining about their managers and some possible negative attitudes of their managers. These issues can be reached out from the following statement: 
"In situations that will be perceived as if I am complaining about my manager. So, generally, I try to remain silent. Especially, I prefer to remain silent on issues that directly concern my manager or that will be perceived as if I am complaining about him. For example, communication problems, some harsh attitudes, discriminatory behavior, and business-related wrong practices." (Participant from India)

Employees also remain silent when the issues are not related to themselves personally and if there are some unpredictable reactions of their managers depending on their daily moods. These issues can be reached out from the following statement:

"I don't prefer to talk unless the topic is related to my working conditions, my job description, or my manager's negative behaviors towards me. Also, I do not talk about the problems of other employees or the manager's reactions based on daily moods. So, I do not talk about the things that I don't find logical." (Participant from Hungary)

Other issues to remain silent for these employees are rested on the managers' attitudes, decisions, and mentality. These issues can be reached out from the following statement:

"My manager has many problems with his way of doing business, making a good work plan, and attitudes towards employees. Also, he may cause some negative situations because of his lack of vision. This is not just my opinion. He is also aware of this and very sensitive. So, he is not willing to talk about these issues. In the case of talking to him, he immediately reacts negatively and tries to use his authority. Our department mainly consists of foreign employees and our coordinator is Polish due to company policy. For once, some of the foreign friends expressed their thoughts about our manager. A discussion broke out at that moment. So, I do not want to talk about the situations that important for me but sensitive for my manager to avoid any negative reactions." (Participant from Uzbekistan)

b-) The reasons for remaining silent: The reasons for remaining silent for the employees who speak up occasionally are based on different situations. Managers' refusal for their discriminatory behaviors, avoidance from managers' negative attitudes, afraid of being perceived as a constant complainer, and worried about being discriminated against are some of these reasons. These reasons can be reached out from the following statement:

"I tried to speak many times but my manager does not admit that he discriminates. Even though not in practice, the mention of discrimination would create the perception that managers commit a crime according to the law. For this reason, my manager ended up our conversation when I was expressing my opinion. So, I do not want to be perceived as someone who complains constantly and tries to put his manager at risk. Because other managers also may see you as risky person since they talk to each other about employees. In addition to this injustice, there is no need to take the reaction of all managers and being discriminated against." (Participant from Turkey)

The legal processes of permits for foreigners (for non-EU citizens) in the country and the economic satisfaction of the current job are other reasons to remain silent for these employees. These reasons can be reached out from the following statement: 
"Obtaining residence and work permits in Poland is both difficult and takes a long time. Because the service sector in the public sphere is very insufficient and uncontrolled. Especially if you do not come from their preferred countries (Ukraine, Bulgaria, etc.). So, it may be more reasonable to remain silent as long as the economic conditions of the job do not deteriorate and there are no major problems." (Participant from India)

Lack of rational justification in managers' reactions and the situation is related to other employees are some other forms of the reasons to remain silent. These reasons can be reached out from the following statement:

"I remain silent as there is no situation or problem-related to me or I prefer to remain silent when there are some behaviors of my manager that he develops for no logical reasons." (Participant from Hungary)

Avoidance from stress and the feeling of despair about being justified are also important reasons for employees to remain silent. These reasons can be reached out from the following statement:

"There is no need to talk. Because I will not get results and will get stressed unnecessarily for an issue that I am right about. That's why I prefer to talk about topics that will not lead to these situations." (Participant from Uzbekistan)

c-) The effect of remaining silent on employees: Remaining silent causes some negative effects on these employees' mood, productivity, motivation, and self-esteem. These effects can be reached out from the following statements:

"I used to try to stay as positive and say "I'm in a foreign, I'm learning to be more patient". But then I felt that this situation was nothing more than suppression. This also directs me to question myself constantly and get angry. I do not take part in the meetings unless it is mandatory. When I attend meetings, mostly I prefer to be a listener. Because I think the things that I say will be perceived negatively even if they are positive. And I'm afraid of remaining silent will turn into behavior and negatively affect other areas of my life." (Participant from Turkey)

"I am not conveying suggestions or practices that may be more useful for the job or team. This causes me to do the things related to the job that I think is problematic in the same way and experience stress." (Participant from India)

"Remaining silent does not affect me negatively. Because I prefer to remain silent and not react to these situations. Also, these situations are not directly related to me. For example, the manager is having problems with others or the manager adopts an attitude to everyone without a rational justification. It does not bother me as there is no logical behavior-reaction relationship." (Participant from Hungary)

"The issues that we complain about are really directly related to the job/workplace. I mean the effect of our manager's attitudes on the job/workplace. Unless our manager changes his attitudes, we will 
be continuing with lower motivation. In fact, we can be more effective and efficient. But this situation negatively affects both our workplace and our development." (Participant from Uzbekistan)

\section{The Employees Who Always Speak Up}

Table 3 shows the thematic summaries of employees' responses who always speak up based on one question. The evaluations for these themes through this question and the original form of the responses given by the participants are below.

Table 3. The Employees Who Always Speak Up

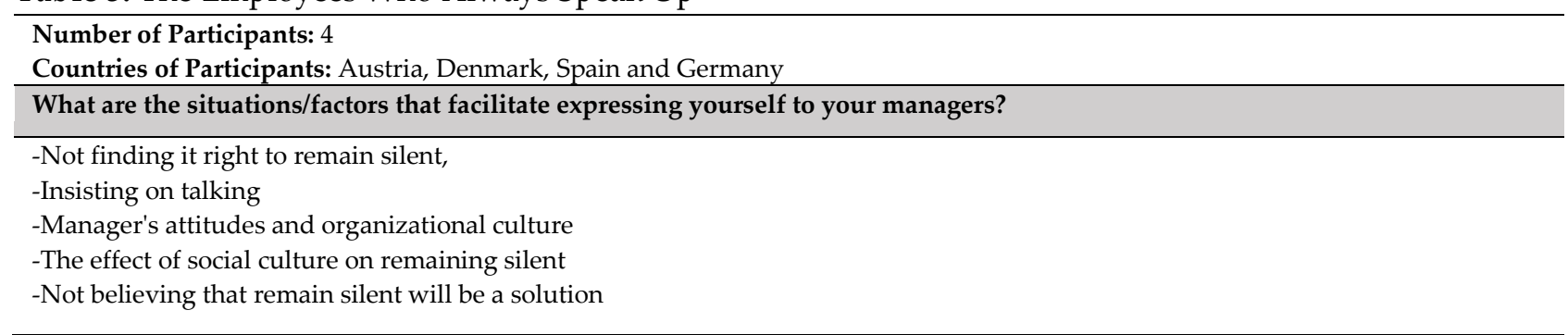

a-) The situations that facilitate speaking up for employees: Employees who always speak up explain the situations that make it easier to talk to their managers with different perspectives. For example; not finding it right to remain silent, insisting on talking, manager's attitudes, organizational culture, the effect of social culture on remaining silent, and not believing that remaining silent will be a solution are some of these perspectives. These perspectives can be reached out from the following statements:

"I do not prefer to remain silent on any subject that I deem necessary. My current manager is from Poland, and when I compare with managers from other European countries, I think my manager is more closed for communication. Maybe it's about that the foreigners are not welcomed in general. For this reason, being able to speak is more related to my insistence on speaking about the things that I feel uncomfortable with, rather than my manager being open to communication and criticism." (Participant from Austria)

"Most of the employees in my workplace are foreigners. My manager is also Italian and very open to communication. The management mentality of the company which I work for is also in the process of change. This change and my manager's understanding make communication easier." (Participant from Denmark)

"I can say that working with Polish employees or managers is more difficult when I compare to people in my own culture. Because there are many managerial positions in the company which I work for and all positions are related to each other. So, you have to talk about everything, positive or negative. That's why I don't remain silent. I speak up even though it is not easy. I mean, the situation of being able to speak is basically about myself because the culture where I grew up and my family did not teach me to remain silent and it doesn't sound right to me either". (Participant from Spain) 
"Although my Polish manager is more closed to communication than other managers, he needs to communicate with me because he needs my profession. I am aware that he is not pleased when I express the situations that I do not find the right. But this doesn't affect my motivation negatively. Because in order to fulfill my tasks, I have to convey what is good or bad. If there is a problem that relates to me, I have to solve this problem for my own good. Remaining silent should never be a solution." (Participant from Germany)

\section{DISCUSSION AND IMPLICATIONS}

When the findings of the study are considered in general, it is possible to say that more than half of the employees who took part in this study remain silent. Different studies might support this finding. For example, it is stated that half of the employees within Fortune 100 multinational organizations feel safe to express themselves (Burris et al., 2010, as cited in Jahangir \& Abdullah, 2017, p. 148) and 7 out of 10 employees in American organizations remain silent (Nemeth \& Nemeth-Brown, 2003). Another finding of this study shows that the employees from Eastern countries remain more silent than employees from Western countries. The reasons for remaining silent are employees' social culture and personality, the difficulty of obtaining legal rights in Poland, and some economic reasons. In contrast to these findings, the employees from Western countries explain their reasons for speaking up attributing to their upbringing, cultures, personality, and social rights that they already have. The responses for the question of "The Employees Who Always Speak Up" can support this evaluation.

\section{The Issues in which Organizational Silence Occurs}

This study shows that employees remain silent about different issues. Employees' relationships with their managers could be considered as the most significant issue. Because, the employees mostly remain silent when the issues are about their managers' attitudes, behaviors, perceptions, decisions, daily moods, and mentality. There are different researches that support this finding as it is stated that employees from multinational companies are afraid of the negative reactions from their superiors in case of self-expression, and they remain silent (Detert \& Edmondson, 2005). Additionally, the theoretical model developed by Milliken (2003) indicates the situations about manager's attitudes and states that organizational structure and managerial practices are important factors for organizational silence. Hence, in accordance with the literature, the current study draws attention to the relationship between managers' attitudes or behaviors and organizational silence (Vakola \& Bouradas, 2005) and underlines the effect of manager's negative attitudes, discriminatory behaviors, insensitivity and some cultural-based reactions on employee silence.

The findings also show that employees remain silent where the issues are related to their working conditions as they cannot predict how their manager will react. There is a similar finding refers that the

| 968 I employees feel uncomfortable when they need to talk to their managers about working conditions (Çakıc1, 2008). Thus, this finding is consistent with the literature and emphasizes that the employees remain silent when the situation is related to their salaries, working schedule, planning overtime, etc.

In addition to these issues, the employees remain silent where the content of the speech might be perceived as a problem by managers; other members have some problems with managers or in situations 
that will be perceived as if the employees complain about their managers. This finding points to two important conclusions. The employees remain indifferent despite the possibility of experiencing similar problems to other members in the future. Also, the employees' experiences may have created a perception that every request for speaking will be seen as a problem. Thus, it is believed that remaining silent will eliminate the perception of a problematic employee and constant complainer.

\section{The Reasons for Organizational Silence Behavior}

The findings show that employee silence is based on different reasons. The first reason is totally associated with managers' harsh and angry reactions and refusal for their discriminatory attitudes. Similarly, the employees also remain silent as they are worried about being discriminated against, they do not want to be perceived as someone who complains constantly and they cannot rationalize their managers' behaviors. These findings are supported by different studies claiming that employees remain silent to avoid some negativities. For example, negative feedback from managers (Morrison \& Miliken, 2000; Vakola \& Bouradas, 2005), being labeled as a negative person who damages relationships (Milliken et al., 2003), being perceived as a threat, troublemaker and complainant (Akbarian et.al., 2015; Milliken et al., 2003; Vakola \& Bouradas, 2005), fear of being excluded and perceived as problematic (Kahveci \& Demirtaş, 2013) and receiving negative reactions from managers (Nafei, 2016).

Some of the other reasons why employees remain silent are related to feelings of hopelessness and stress. This finding is consistent with the literature and it is claimed that employees tend to show silence behavior to not remain under the stress (Çakıc1, 2010). One another reason for remaining silent underlines that employees do not speak up as they feel desperate about change. Because the employees think that remaining silent will be the most reasonable reaction as there will not be any change in case of speaking up. Based on their experience, this can be considered as a reasonable justification due to the fact that the outcome remains unchanged despite being right in the face of a problem and recommendations for the job are not taken into account. For this reason, the employees show no effort to speak up and share their suggestions/ideas as they have experienced such situations. As cited, the employees believe that nothing will change and their problem will not be solved if they talk about their suggestions and problems (Ayduğ et al., 2017; Brinsfield, 2009; Kahveci, 2010; Premeaux, 2001).

Employees' culture and personality are two other different reasons for remaining silent. Because the employees' cultures emerge as a situation that prevents them when they would like to speak up or give a reaction. There are similar findings that emphasize that cultural components and cultural cases (e.g. power distance) have an effect on organizational silence (Huang et al., 2005). Additionally, the relationship between personality and organizational silence (Brinsfield, 2009; Dilek \& Taşkıran, 2016) also supports another finding of this study. While some employees cannot speak up as their personality traits do not allow them to give a reaction, some others think that they can speak up but prefer to remain silent as they can't predict their own reactions (avoiding reacting negatively and too excessively).

The last reason for employees to remain silent is the legal processes of work/residence permits in the country. Because work and residence permits are seen as a challenge in the country due to bureaucratic stages and as it takes more than predicted time (for non-EU citizens). Thus, when they 
consider their working conditions as satisfactory (especially economic), they do not want to take a risk changing their jobs to avoid starting legal processes from the very beginning and get long-term permits.

\section{The Effect of Organizational Silence on Employees}

Silence causes some effects on employees' mood, efficiency, motivation, behaviors, and selfesteem. As a result of these effects, they can get angry and stressed easily, their motivation is negatively affected and they cannot focus on their tasks to be more effective at their workplace, they question themselves and feel suppressed. Different studies through the literature refer to the similar effects of organizational silence on employees. For example, negative effects on employee's job satisfaction, commitment, motivation, well-being, confidence, belonging, resistance to stress, and appreciation (Beer \& Eisenstat, 2000; Çakıc1, 2008; Hozouri et al., 2018; Karaca, 2013; Milliken et al., 2003; Milliken \& Morrison, 2003; Morrison \& Milliken, 2000; Shojaie et al., 2011; Vakola \& Bouradas, 2005).

Silence also leads employees to some fears that related to the idea of what they say will always be perceived negatively. Because employees remain silent as they believe that their managers will perceive their ideas generally as negative and their working conditions will be affected negatively in case of speaking up (Milliken et al., 2003).

The findings also reveal that silence is seen as an obstacle for employees to share their ideas/suggestions about their job/workplace and self-improvement. Because of the silence' effect, the employees hide their useful advice about their job and feel barriers for personal development as they believe that speaking up on organizational problems or concerns related to the work is useless and can be dangerous (Morrison \& Milliken, 2000).

\section{The Situations that Facilitate Speaking Up}

The situations that facilitate self-expressing are based on several factors. These factors are associated with employees' attitudes towards silence, their personalities and social cultures, managers' positive behaviors and organizational culture. Because employees insist on speaking up and do not remain silent as they do not find it right to remain silent or do not believe that remaining silent will be a solution based on their personalities and social culture. Therefore, it is possible to say that the most obvious reason for remaining silent among these reasons is social culture and employees who do not remain silent or do not find it right to remain silent are mostly people who represent the western culture. In this context, the effect of social culture on individuals' behavior in business life as well as their daily life becomes more understandable. There are also different studies that support this finding and show that silence is less preferred by members of western or individualistic cultures (Bowen \& Blackmon, 2003; Durak, 2012; Panteli \& Fineman, 2005). Therefore, the social culture to which one belongs has a significant effect in determining the reaction of employees to silence in organizational life. Additionally, the supportive and positive attitudes of managers and organizational culture are effective factors that facilitate employees' self-expression. Different studies mention similar relationships through focusing on organizational culture and structure, nationality, organizational support, managerial practices, and personality (Akbarian et al., 2015; Bergeron \& Thompson, 2020; Bowen \& Blackmon, 2003; Çetin et al., 
2016; Doğan \& Yılmaz, 2020; Erat et al., 2017; Misırdalı Yangil \& Beydilli, 2016; Sholekar \& Shoghi, 2017; Şimşek \& Aktaş, 2014).

\section{Implications}

The employee silence problem can be solved although it is a common problem for every organization. Therefore, the first and important point to be considered is organizational culture. Because organizational culture is the main component that can shape and lead managers' behavior and attitudes as these attitudes and behaviors are the most effective reasons for organizational silence. As a result of well-structured culture, managers will not be able to find a work environment where they can develop any kinds of negative behaviors, and employees will have their speaking comfort.

While some employees think that they are discriminated against because of their beliefs or nationality, others remain silent due to cultural reasons or their personality. Thus, managers should behave more sensitively and show equal interest. For example, managers should make an equitable decision when they plan employees' working schedules, clarify their tasks or deal with their problems, and they should not consider the employees' cultures, religions, or personalities in this process as a criterion. By this sensitivity, all employees will have a mindset that their managers have a sense of equality, instead of discriminatory behaviors. As a result, organizations will have a structure that is ready to accept all different cultures and opinions to solve employees' concerns about self-expression and make diversity strength in the organizational life.

The managers should be open to communicate with employees to solve their problems, have their suggestions, and support their development. For this reason, the importance of managers' selection comes out, and employers are recommended to utilize multiple observation and evaluation techniques while selecting managers. Also, the current managers who have some obstacles for communication should be directed to different supportive training or workshops based on assessments. Otherwise, employee silence will harm the organization itself and its members.

It is important that the employers and managers should take an active role in the process of obtaining legal rights that might negatively affect employee productivity and seek common solutions with relevant institutions. In addition to other reasons for silence, such situations that limit employees may prevent them from demonstrating their abilities. Because the employees will remain silent in order not to lose their current rights and they will not be willing to contribute the competencies they have to the organizations.

It is recommended that the participants should be selected from the same organization and department on the condition that more participants from fewer countries for future studies. Thus, the effect of organizational culture and structure will be eliminated, and the effect of participants' cultures on organizational silence will be observed more clearly. 
Murat AYDINAY

\section{Ethics Committee Permission}

This article is not part of a working group that requires ethical committee approval.

浓浓 


\section{References}

Acaray A., Gündüz Çekmecelioğlu H., \& Akturan A. (2015). The analysis of the relationship between organizational culture and organizational silence. The Journal of Academic Social Science Studies, 32, 39-157. http://dx.doi.org/10.9761/JASSS2645

Adl.org, $\quad$ ADL $\quad$ Global $100 . \quad$ (2021, April $\quad$ 27). https://www.adl.org/sites/default/files/documents/assets/pdf/press-center/Global-A-S-SurveyCountries.pdf.

Akbarian, A., Ansari, M. E., Shaemi, A., \& Keshtiaray, N. (2015). Organizational silence: Why and how can overcome?. Saussurea, 3(1), 39-44.

Argyris, C., \& Schön, D. (1978). Organizational learning: A theory of action perspective. Addison Wesley. https://doi.org/10.1177/017084068000100310

Ayduğ, D., Himmetoğlu, B., \& Turhan E. (2017). Evaluating the opinions of teachers on organizational silence through a qualitative study. BoluAbant Izzet Baysal University Journal of Faculty of Education, 17(3), 1120-1143. https://doi.org/10.17240/aibuefd.2017.17.31178-338812

Baltacl, A. (2018). A conceptual review of sampling methods and sample size problems in qualitative research. Journal of Bitlis Eren University Institute of Social Sciences, 7(1), 231-274.

Beer, M., \& Eisenstat, R. (2000). The silent killers of strategy implementation and learning. Sloan Management Review, 41, 29-40.

Bergeron, D., \& Thompson, P. (2020). Speaking up at work: The role of perceived organizational support in explaining the relationship between perceptions of organizational politics and voice behavior. The Journal of Applied Behavioral Science, 56(2), 195-215.

Botero, I. C., \& Van Dyne, L. (2009). Employee voice behavior: Interactive effects of LMX and power distance in the United States and Colombia. Management Communication Quarterly, 23(1), 84-104.

Bowen, F., \& Blackmon, K. (2003). Spirals of silence: The dynamic effects of diversity on organizational voice. Journal of Management Studies, 40(6), 1393-1417.

Brinsfield, C. (2009). Employee silence: Investigation of dimensionality, development of measures and examination of related factors. (Unpublished master's dissertation). The Ohio State University.

Brinsfield, C. T. (2013). Employee silence motives: Investigation of dimensionality and development of measures. Journal of Organizational Behavior, 34(5), 671-697. https://doi.org/10.1002/job.1829

Çakıcı, A. (2008). A research on issues, causes and perceptional results of silence at organizations. Journal of Çukurova University Institute of Social Sciences, 17(1),117-134.

Çakıcı, A. (2010). Örgütlerde işgören sessizliği: Neden sessiz kalmayı tercih ediyoruz? (Employee silence in organizations: Why we prefer to stay silent?). Detay Yayıncillk.

Cavise, H. A. (2019). Strategies for managing employee self-expression in the workplace. (Unpublished doctoral thesis). Walden University Doctor of Business Administration.

Çavuş, M. F., Develi, A., \& Sarioğlu, G. S. (2015). Mobbing and organizational silence: A research on energy sector employees. Journal of Business and Economics Studies (JBES), 3(1), 10-20. 
Çetin, C., Karabay, M. E., Özcan, E. D., \& Taşkıran, E. (2016). The effect of personality traits on organizational silence: A research on service industry. In L. Altınay \& S. Poudel (Eds.), Enhancing customer experience in the service industry: A global perspective (pp.130-152). Cambridge Scholar Publishing.

Creswell, J. W., \& Clark, V. L. P. (2016). Designing and conducting mixed methods research. Sage.

Deniz, S. (2019). A research on determining the reasons for organizational silence of hospital employees. Balkan and Near Eastern Journal of Social Sciences, 05(03), 96-103.

Detert, J., \& Edmondson, A. (2005). No exit, no voice: The bind of risky voice opportunities in organizations. Academy of Management Proceedings, 1-6. https://doi.org/10.5465/ambpp.2005.18780787.

Dilek, Y., \& Taşkiran, E. (2016). A research for the determination of the effects of personality traits on the organizational silence. Bartin University Journal of Faculty of Economics and Administrative Sciences, $7(13), 402-434$.

Doğan S., \& Yılmaz M. (2020). The effects of organizational culture on organizational silence in the health institutions. Business \& Management Studies: An International Journal (BMIJ), 8(2), 1523-1545. http://dx.doi.org/10.15295/bmij.v8i2.1440

Durak, İ. (2012), Korku kültürü ve örgütsel sessizlik. Ekin Yayınevi.

Durak, İ. (2014). Relationships between organizational silence and demographics, institutional factors: A study on academic staffs. Atatürk University Journal of Economics and Administrative Sciences, 28(2), 89-108.

Dyne, L., Ang, S., \& Botero, C. (2003). Conceptualizing employee silence and employee voice as multidimensional constructs. Journal of Management Studies, 40(6), 1359-1392.

Erat, S., Alniacik, U., Ciftcioglu, A., \& Akçin, K. (2017). Effect of perceived organizational support on organizational silence and task performance: A study on academicians. Journal of Global Strategic Management, 1, 35-43.

Eroğlu, A. H., Adigüzel, O., \& Özturk, U. C. (2011). Dilemma of silence vortex and commitment: Relationship between employee silence and organizational commitment. Suleyman Demirel University The Journal of Faculty of Economics and Administrative Sciences, 16(2), 97-124.

Hofstede Insights, Country Comparison. (2021, April 29). https://www.hofstede-insights.com/countrycomparison/.

Hozouri, M., Yaghmaei, M., \& Bordbar, H. (2018). Clarifying the impacts of organizational silence on organizational commitment with controlling the effects of organizational rumors. Management Science Letters, 8, 533-542. http://dx.doi.org/10.5267/j.msl.2018.5.002

| 974 | Huang, X., Van de Vliert, E., \& Van Der Vegt, G. (2005). Breaking the silence culture: Stimulation of participation and employee opinion withholding cross-nationally. Management and Organization Review, 1(3), 459-482.

Jahangir, M., \& Abdullah, M. (2017). A review of organizational silence antecedents and its impact on job attitudes. Sarhad Journal of Management Sciences, 3(01), 146-159. 
Kahveci, G. (2010). The relationship between organizational silence and organizational commitment in primary schools (Unpublished master's dissertation). Firat University Institute of Social Sciences.

Kahveci, G., \& Demirtaş, Z. (2013). Development study of organizational silence scale for teachers. Electronic Journal of Social Sciences, 12, 167-182.

Karaca, H. (2013). An exploratory study on the impact of organizational silence in hierarchical organizations: Turkish national police case. European Scientific Journal, 9(23), 38-50.

Karakas, A. (2019). The relationship between perceived supervisor support and the aspects of organizational silence. African Journal of Hospitality, Tourism and Leisure, 8(3), 1-19.

Lam, L. W., \& Xu, A. J. (2019). Power imbalance and employee silence: The role of abusive leadership, power distance orientation, and perceived organizational politics. Applied Psychology, 68(3), 513546.

Liang, H., \& Yeh, T. (2020). The effects of employee voice on workplace bullying and job satisfaction: The mediating role of leader-member exchange. Management Decision, 58, 569-582. https://doi:10.1108/MD-01-2019-0112

Liu, D., Wu, J., \& Ma, J. (2009). Organizational silence: A survey on employees working in a telecommunication company. International Conference on Computers and Industrial Engineering, 1647 - 1651. http://dx.doi.org/10.1109/ICCIE.2009.5223551

McNabb, D. E. (2015). Research methods for political science: Quantitative and qualitative methods. Routledge.

Milliken, F., \& Morrison, E. (2003). Shades of silence: Emerging themes and future directions for research on silence in organizations. Journal of Management Studies, 40, 15631568. https://doi.org/10.1111/1467-6486.00391.

Milliken, F., Morrison, E., \& Hewlin, P. (2003). An exploratory study of employee silence: Issues that employees don't communicate upward and why. Journal of Management Studies, 40(6), 1453-1476.

Misirdalı Yangil, F., \& Beydilli, E. (2016). The relation between organizational silence and personality characteristics: A study on thermal hotels. International Journal of Business and Management Invention, 5(11), 31-36.

Morrison E. W., \& Milliken, F. J. (2000). Organizational silence: A barrier to change and development in a pluralistic world. The Academy of Management Review, 25(4), 706-725.

Morrison, E. W., \& Milliken, F. J. (2000). Sounds of silence. Stern Business, 25, 31-35.

Nafei, W. A. (2016). Organizational silence: Its destroying role of organizational citizenship behaviour. International Business Research, 9(5), 57-75.

Nemeth, C. J. (1985). Dissent, group process and creativity: The contribution of minority influence. In: Lawler, E. (Ed.) Advances in group processes, 2, (pp. 57-75). JAI Press.

Nemeth, C. J., \& Nemeth-Brown, B. (2003). Better than individuals? The potential benefits of dissent and diversity for group creativity. In Paulus, P. (Eds), Group creativity: Innovation through collaboration (pp. 63-84). Oxford University Press, Incorporated.

Nielsen, R.P. (2003). The politics of ethics: Methods for acting, learning, and sometimes fighting, with others in addressing ethics problems in organizational life. Oxford University Press. 
Paksirat, V., \& Taheri, A. (2018). Organizational silence and occupational burnout with job performance. Journal of System Management, 4(4), 39-50.

Panteli, N., \& Fineman S. (2005). The sound of silence: The case of virtual team organising. Behaviour and Information Technology, 24(5), 347-352.

Pew Research Center, Eastern and Western Europeans Differ on Importance of Religion, Views of Minorities, and Key Social Issues. (2018, October 29). https://www.pewforum.org/2018/10/29/eastern-and-western-europeans-differ-on-importance-ofreligion-views-of-minorities-and-key-social-issues/.

Pinder, C., \& Harlos, K. (2001). Employee silence: Quiescence and acquiescence as response to perceived injustice. Research in Personnel and Human Resource Management, 59, 331-369.

Podsakoff, P. M., Mackenzie, S. B., Paine, J. B., \& Bachrach, D. (2000). Organizational citizenship behaviours: A critical review of the theoretical and empirical literature and suggestions for future research. Journal of Management, 26(3), 513-563.

Premeaux, S. F. (2001). Breaking the silence: Toward an understanding of speaking up in the workplace. (Unpublished master's dissertation). Louisiana State University Department of ManagementBusiness Administration.

Premeaux, S. F., \& Bedeian, A. G. (2003). Breaking the silence: The moderating effects of self-monitoring in predicting speaking up in the workplace. Journal of Management Studies, 40(6), 1537-1562.

Quinn, R., \& Spreitzer, G. (1997). The road to empowerment: Seven questions every leader should answer. Organizational Dynamics, 26(2), 37-50.

Sherf, E. N., Sinha, R., Tangirala, S., \& Awasty, N. (2018). Centralization of member voice in teams: Its effects on expertise utilization and team performance. Journal of Applied Psychology, 103(8), 813-827. https://doi:10.1037/ap10000305

Shojaie, S., Matin, H., \& Barani, G. (2011). Analyzing the infrastructures of organizational silence and ways to get rid of it. Procedia - Social and Behavioral Sciences, 30, 1731-1735. https://doi.org/10.1016/j.sbspro.2011.10.334.

Sholekar, S., \& Shoghi, B. (2017). The impact of organizational culture on organizational silence and voice of faculty members of Islamic Azad university in Tehran. Iranian Journal of Management Studies (IJMS), 10(1), 113-142.

Şimşek, E., \& Aktaş, H. (2014). Interaction between organizational silence, personality and life satisfaction: A study in the public sector. Anadolu University Journal of Social Sciences, 14(2),121-136.

Şimşek, Y., \& Gürler, M. (2019). A study on employee voice and its effect on work engagement: Explicating from the Turkish teachers' perspectives. International Education Studies, 12(7), 80-92. https://doi:10.5539/ies.v12n7p80

Slade, M.R. (2008). The adaptive nature of organizational silence: a cybernetic exploration of the hidden factory. The George Washington University-ProQuest Dissertations Publishing. 
Timming, A. R. (2012). Tracing the effects of employee involvement and participation on trust in managers: An analysis of covariance structures. The International Journal of Human Resource Management, 23(15), 3243-3257. https://doi:10.1080/09585192.2011.637058

Vakola, M., \& Bouradas, D. (2005). Antecedents and consequences of organisational silence: An empirical investigation. Employee Relations, 27, 441-458. https://doi.org/10.1108/01425450510611997.

Wikipedia, Western World. (2021, April 28). https://en.wikipedia.org/wiki/Western_world\#Western/European_culture.

Yıldırım, A., \& Şimşek, H. (2016). Sosyal bilimlerde nitel araştırma yöntemleri (10. Baskı). (Qualitative research methods in social sciences (10th Edition). Seçkin Yayıncılık.

$$
\text { 邹 }
$$

